\title{
体内埋込型機器用経皮的通信のための小型アンテナ
}

\section{Miniaturized antenna for transcutaneous radio communication devices}

○横井 啓太* 青木 広宙* 越地 耕二*

本間 章彦** 巽 英介** 妙中 義之**

OKeita YOKOI*, Hirooki AOKI*, Kohji KOSHIJI*,

Akihiko HONMA**, Eisuke TATSUMI**, Yoshiyuki TAENAKA**

東京理科大学大学院* 国立循環器病センター**

Tokyo University of Science graduate school*, Research Institute, National Cardiovascular Center**

\section{1．まえがき}

各種体内埋込機器システムを生体に埋め込んだ際、体外に おいて動作状況を非侵襲に監視、制御することが必要である [1]。小型アンテナを用いる方法は従来のような生体の皮膚を 貫くケーブルや結合素子の体表までのケーブルは不要になり、 結合を気にするという煩わしさがなく QOL(Quality of Life)が 向上し、通信可能距離の向上が期待できる[2]。アンテナを生 体内に埋め込むため小型で性能の良いものが要求されるが、 小型アンテナを生体付近に配置すると生体からの影響を受け その特性は変化してしまう。そこで生体付近に小型アンテナ を配置した際の特性の検討を TLM 法(Transmission Line Modeling Method)による電磁界解析で行ったので報告する。

2. 容量装荷型ループアンテナ

2 - 1 周波数とアンテナの大きさ

アンテナ長は高周波の電波を使用するほどアンテナの大き さが小さく出来るが、一般に高周波は生体に吸収されやすく、 電磁波の電界成分は生体に影響を及ぼしやすい。一方、透磁 率は真空中の值に等しく皮膚の影響を受けにくい。本稿では アンテナ近傍において磁界は優勢であり、皮膚の透過特性に 優れたループアンテナを電気的に小型化低周波化した容量装 荷型ループアンテナを採用した[1][2]。

\section{$2 \cdot 2$ 小型化の原理}

Fig.1 に示したアンテナの等価回路を伝送線路とみなした 終端に静電キャパシタ $\mathrm{C}$ を接続した時、入カインピーダンス は(1)式で与えられる。インピーダンスの整合時に(1)式の分子 が 0 となるので、(2)式となる。ここで、キャパシタ容量 Cが

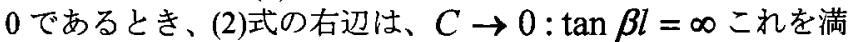
たす線路長は、 $l=\lambda / 4$ となる。一方、キャパシタ容量 $\mathrm{C}$ がある有限值を持てば、(2)式を満たす $\tan \beta l$ の值は小さく なるので、伝送線路のリアクタンスを 0 とする線路長は、 $l<\lambda / 4$ となり、(1/4)波長よりも短くすることが出来る。

\section{3. 解析}

Fig.2(a)(b)に示すチューニングループ(直径 $\mathrm{Dt}=21[\mathrm{~mm}]$, 固 定。ループ長 65.97[mm])からなるチューニング面と、(b)に示 すピックアップループ(直径 $\mathrm{Dp}=11[\mathrm{~mm}]$, 比誘電率 $\varepsilon_{\mathrm{r}}=2.17$, tan $\delta=0.00085)$ からなるピックアップ面が、表裏一体となった構 造をもつ。このアンテナ近傍に筋肉モデル $(50[\mathrm{~mm}] \times 50[\mathrm{~mm}]$ $\times 3[\mathrm{~mm}])$ を配置した Fig.2 (c)(d)。筋肉との距離を $\mathrm{t}$ とし。

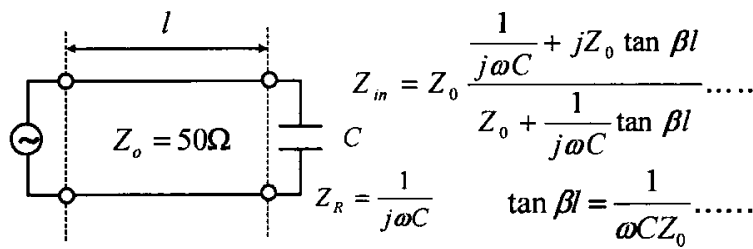

Fig.1 Equivalent circuit using transmission line

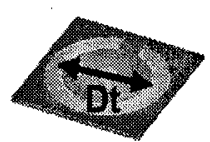

(a)Tuning loop

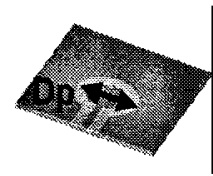

(b)Pick up loop (c)parallel Fig.2 Simulated models

\section{4. 解析結果}

Fig.3にキャパシタ容量 2.2[pF]、平行、垂直に $2[\mathrm{~mm}]$ 離して 配置した時のリターンロス特性を示す。平行、垂直共にアン テナを筋肉付近に配置することによりアンテナのリターンロ ス特性は大きく変化し、ピーク值の周波数もシフトした。

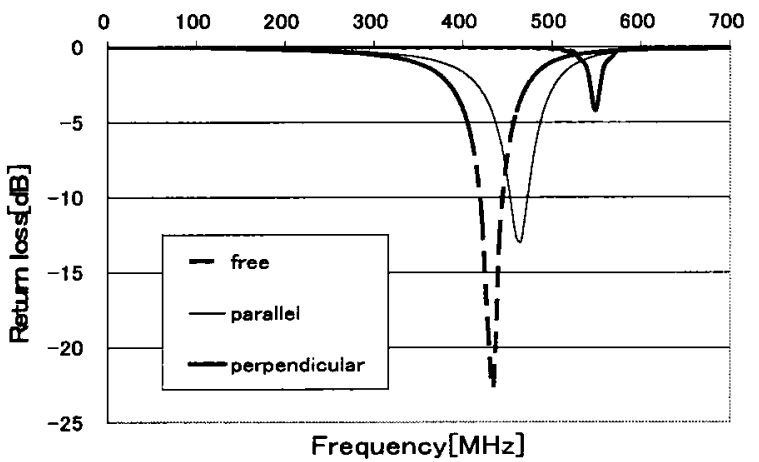

Fig.3 Return loss $(\mathrm{C}=2.4[\mathrm{pF}], \mathrm{t}=2[\mathrm{~mm}])$

これはアンテナを䇗肉表面に配置することにより、アンテ ナの入カインピーダンスが大幅に変化しているためである。

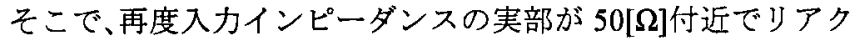
タンスが 0 となるようにキャパシタ容量を平行時 $15.83[\mathrm{pF}]$ 、 垂直時 $1.267[\mathrm{pF}]$ 增加させ整合を取り直した。整合を取り直す ことによってアンテナのリターンロス特性は平行時では一 $26.9[\mathrm{~dB}]$ 、垂直時ではー23.4[dB] 大幅に改善された(Fig.4)。 また、リターンロスの鋭さが異なるのは垂直時の入力インピ 一ダンスが高いためである。

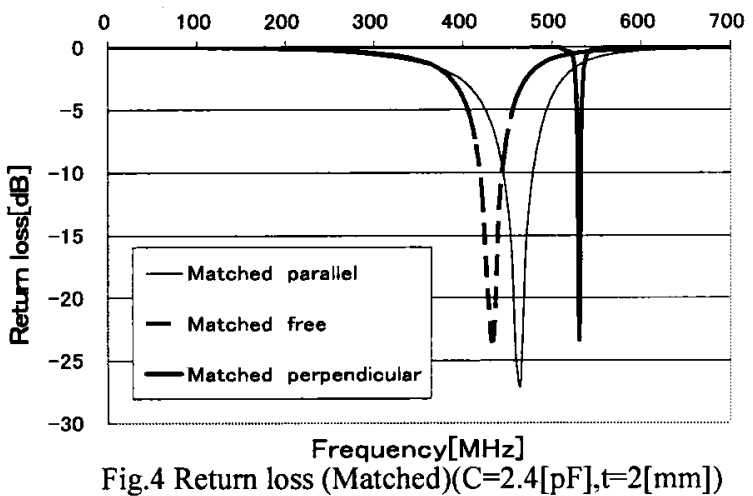

\section{5.あとがき}

Fig.4 Return loss (Matched) $(\mathrm{C}=2.4[\mathrm{pF}], \mathrm{t}=2[\mathrm{~mm}])$

以上、本稿では生体表面にアンテナ配置し、その配置方向 によりリターンロス特性が大きく変化したことを確認した。 また、キャパシタで再度整合を取り直すことによってリター ンロス特性のピーク值は無配置時と同等程度まで改善された。 6. 参考文献

[1]小林健太, 柴健次, 越地耕二, 島田光功, 直野義昭, 妙中 義之:「体内埋込型インスリン注入システム用経皮通信システ 厶の試作・評価」, 人工藏器, Vol.32, No.2, S-164 (2003 年) [2]横井啓太, 青木広宙, 越地耕二, 本間章彦, 巽英介, 妙中 義之:「体内埋込型機器用ワイヤレス通信のための小型アンテ 十の検討」, 第 18 回「電磁力関連のダイナミクス」シンポジ ウム講演論文集, pp.125-128 (2006 年) 